\title{
Fungsi Tuor Bagi Orang Mandailing
}

\author{
Yulia Risa ${ }^{1}$, Emizal Amri ${ }^{2}$ \\ ${ }_{1,2}$ Universitas Negeri Pandang \\ Email: yuliarisa73801@gamail.com, emizalamri@fis.unp.ac.id
}

\begin{abstract}
Abstrak
Penelitian ini bertujuan untuk menganalisis fungsi pemberian Tuor dalam adat Mandailing di Jorong Ranto Panjang Nagari Rabi Jonggor Kecamatan Gunung Tuleh Kabupaten Pasaman Barat. Fokus dari artikel ini yaitu pemberian Tuor (maskawin) dari pihak laki-laki kepada perempuan dalam adat perkawinan orang Mandailing di Ranto Panjang. Mengingat masyarakat yang berda di Pasaman Barat memiliki suku bangsa yang beragam seperti Minang, Melayu, Mandailing dan Jawa yang memiliki kebudayaan berbedabeda disetiap daerahnya. Akan tetapi pemeberian Tuor tetap dipertahankan dan selalu ada sebelum upacara perkawinan orang Mandailing baik yang menikah dengan sesama suku mandailing maupun tidak dengan orang Mandailing. Acara penetapan Tuor dilaksanakan pada acara Marsapa (meminang). Teori yang digunakan dalam artikel ini adalah teori fungsionalisme yang dikemukakan oleh Bronislaw Malinowski. Penelitian dilakukan dengan menerapkan pendekatan kualitatif dengan tipe Etnografi. Informan dipilih secara pusposive sampling. Data dikumpulkan melalui teknik wawancara mendalam (indepth interview), observasi, studi dokumen. Teknik analisis data mengacu pada teknik analisis etnografi yang dikembangkan oleh Miles dan Huberman melipiti: data reduction (reduksi data), data displey (penyajian data), verification analysis (menarik kesimpulan). Berdasarkan hasil penelitian dapat disimpulkan fungsi pemberian Tuor pada masyarakat Mandailing di Ranto Panjang adalah: (1) penguatan ikatan dua keluarga; (2) menjunjung tinggi tradisi yang diwarisi dari generasi terdahulu; (3) menghormati orang tua si gadis; (4) penghargaan terhadap status pendidikan perempuan; dan (5) mendapatkan legalitas perkawinan secara adat.
\end{abstract}

Kata kunci: Batak Mandailing, Perkawinan, Tuor, Tradisi

This study aims to analyze the function of giving Tuor in the Mandailing custom in Jorong Ranto Panjang Nagari Rabi Jonggor, Gunung Tuleh District, West Pasaman Regency. The focus of this article is the giving of Tuor (dowry) from the man to the woman in the marriage custom of the Mandailing people in Ranto Panjang. Considering that the people in West Pasaman have various ethnic groups such as Minang, Malay, Mandailing and Javanese who have different cultures in each region. However, the provision of Tuor is maintained and always exists before the marriage ceremony of the Mandailing people, whether they are married to fellow Mandailing tribesmen or not to the Mandailing people. The Tuor determination event was held at the Marsapa (promising) event. The theory used in this article is the theory of functionalism proposed by Bronislaw Malinowski. The research was conducted by applying a qualitative approach with the type of ethnography. Informants were selected by purposive sampling. Data were collected through indepth interview, observation, and document studies. The data analysis technique refers to the ethnographic analysis technique developed by Miles and Huberman including; data reduction (data reduction), data display (data presentation), verification analysis (drawing conclusions). Based on the results of the study, it can be concluded that the functions of providing tutoring to the Mandailing community in Ranto Panjang are: (1) strengthening the bond of two families; (2) upholding the traditions inherited from previous generations; (3) respect the girl's parents; (4) respect for women's educational status; and (5) obtaining the legality of marriage in a customary manner.

Keywords: Marsapa, Marriage, Tuor, Tradition

\begin{tabular}{l|l|l} 
Received: October 19, 2021 & Revised: December 2, 2021 & Published: December 8, 2021
\end{tabular}




\section{Pendahuluan}

Pasangan yang ingin melaksanakan perkawinan yang sah harus melaksanakan langkahlangkah yang telah ditetapkan baik secara agama dan adat yang berlaku, salah satunya adalah pemberian maskawin. Menurut Kompilasi Hukum Islam, maskawin diartikan sebagai pemberian dari mempelai laki-laki kepada mempelai perempuan, baik berupa barang, uang, atau jasa yang tidak bertentangan dengan hukum Islam. Di beberapa daerah di Indonesia seperti Aceh (Suku Nanggroe Aceh Darussalam), Sumatera Utara (Suku Batak dan Nias), Sulawesi Selatan (Suku Bugis), dan Kalimantan Selatan (Suku Banjar) mempunyai tradisi masing-masing dalam menentukan jumlah dan jenis maskawin. Emas dijadikan sebagai maskawin di daerah Aceh secara umum (Ferdian, 2021). Pada masyarakat Sulawesi selatan pemberian maskawin berupa uang yang dinamakan dengan Uang Panaik (Reski, 2016). Begitu juga pada masyarakat Mandailing maskawin yang diberikan oleh calon mempelai laki-laki yaitu berupa uang yang disebut Tuor (Lanna, 2019).

Tuor merupakan istilah untuk maskawin dalam masyarakat Mandailing, termasuk di Ranto Panjang, Pasaman Barat. Masyarakat Pasaman Barat berasal dari suku berbeda. Suku-suku yang ada di Pasaman Barat antara lain adalah Minang, Jawa, Melayu dan Mandailing, keberagaman tersebut membuat masyarakat memiliki budaya yang berbeda-beda terutama dalam hal perkawinan. Dampak dari keberagaman budaya masyarakat dapat menyebabkan pertukaran budaya bahkan bisa menghilangkan budaya masyarakat jika tidak dipertahankan. Akan tetapi tidak dengan adat Tuor. Adat tersebut masih dipegang teguh oleh masyarakat Mandailing di Pasaman Barat hingga kini.

Istilah Tuor dapat disejajarkan dengan bride price (mas kawin) dalam kajian Antropologi. Bride price adalah sejumlah harta yang diberikan oleh pihak pria kepada pihak gadis, baik kepada gadis itu sendiri maupun kerabatnya (Koentjaraningrat, 2005). Masyarakat Pariaman menyebut Tuor Acara Manjalang dengan uang Bajapuik (Roni, 2016). Uang japuik adalah pemberian dari keluarga pihak perempuan kepada pihak laki-laki yang diberikan pada saat acara Manjapuik Marapulai dan akan dikembalikan lagi pada saat mengunjungi mertua pada pertama kalinya (Yunita, 2013). Sedangkan pada masyarakat Mandailing, Tuor merupakan pemberian secara adat dari pihak laki-laki kepada pihak perempuan sebelum kedua insan melangsungkan pernikahan (perkawinan). Pemberian Tuor dalam adat Mandailing bervariatif, baik dari segi jumlah, cara, proses maupun mekanisme penyerahannya. Acara penentuan besarnya Tuor yang diminta oleh pihak keluarga perempuan ditentukan pada acara Marsapa (Meminang). Jika ada pasangan yang tidak membayar Tuor, maka yang bersangkutan akan dikenakan sanksi adat.

Peneliti tertarik untuk mengangkat topik Tuor dalam masyarakat Mandailing dengan alasan: pertama, Tuor merupakan hal yang sangat penting dalam adat Mandailing. Pentingnya pemberian Tuor pada masyarakat Mandailing dilihat dari catatan perkawinan pada masyarakat Ranto Panjang di Kabupaten Pasaman Barat diperoleh informasi 12 pasangan menikah pada tahun 2020. Dari 12 pasangan tersebut hanya dua pasangan tidak melaksanakan adat pemberian Tuor sesuai dengan latar belakang status sosial calon isterinya. Satu pasangan terkait dengan kasus hamil diluar nikah; dan satunya lagi melakukan kawin lari. Dalam dua kasus seperti itu, pemberian Tuor tidak lagi didasarkan pada status sosial calon isteri, melainkan hanya berupa bantuan modal untuk resepsi pernikahan.

Kedua, dalam masyarakat setempat, Tuor mengandung makna, bahwa pihak laki-laki telah sanggup memberikan Tuor kepada calon isteri yang diharapkannya sesuai dengan permintaan orang tua dan kerabat dari pihak calon isteri. Sebaliknya, keluarga pihak perempuan memaknai bahwa anaknya sudah menemukan calon suami yang mampu memberikan Tuor sesuai dengan yang mereka minta.

Ketiga, Tuor merupakan biaya yang digunakan oleh pihak perempuan sebagai modal untuk melaksanakan pesta perkawinan serta untuk membelikan perlengkapan kamar pihak perempuan. Padahal segera setelah pesta perkawinan, penganten perempuan (isteri) akan di bawa sang suami ke rumahnya, sementara perlengkapan kamar tinggal dirumah orang tua penganten perempuan. 
Besarnya Tuor yang harus diserahkan si laki-laki ditentukan oleh pihak perempuan dengan mempertimbangkan status pendidikan calon isterinya. Dalam perkawinan tahun terakhir ini, terdapat dua kasus pemberian Tuor yang tidak didasarkan pada status pendidikan calon isteri: yang pertama, karena hamil diluar nikah; dan yang kedua, terkait kasus kawin lari. Pada kasus tersebut Tuor tetap diberikan akan tetapi hanya sebagai bantuan untuk penyelenggaraan perkawinan semata ( Mirdan, 50 tahun).

Penelitian yang relevan dengan topik ini pernah dilakukan oleh beberapa peneliti sebelumnya dalam berbagai kajian yaitu Sahriani Siregar membahas tentang hubungan Tuhor dengan terlaksananya pernikahan, besarnya Tuhor yang diminta perempuan mempengaruhi status sosial perempuan di masyarakat (Siregar, 2019). Timothy ESP inti dari penelitiannya, makna tradisi Sinamot mengalami degradasi antara masyarakat kota dan desa (Timothy, 2019). Persepsi masyarakat tentang Uang Panai', besarnya penetapan uang Panai'; dapat menegakkan budaya siri'(malu) (Reski, 2016). Makna tradisi perkawinan Bajapuik, bahwa ada masyarakat yang menerima dan menolak tradisi Bajapuik (Zike, 2020). Edo ferdian mengenai pembayaran mahar wajib hukumnya bagi laki-laki yang ingin menikahi perempuan namun untuk jumlahnya tidak ada batasan melainkan menurut kesanggupan dan kemampuan pihak laki-laki (Ferdian, 2021).

Malinowski dalam melihat fungsi sosial dalam tiga tingkatan abstraksi : (Koentjaraningrat. 2005). 1. Fungsi sosial dari suatu adat, pranata sosial atau unsur kebudayaan pada tingkat abstraksi pertama mengenai pengaruh atau efeknya terhadap adat, tingkah-laku manusia dan pranata sosial yang lain dalam masyarakat; 2. Fungsi sosial dari suatu adat, pranata sosial atau unsur kebudayaan pada tingkat abstraksi kedua mengenai pengaruh atau efeknya terhadap kebutuhan suatu adat atau pranata lain untuk mencapai maksudnya, seperti yang dikonsepsikan oleh warga masyarakat yang bersangkutan; 3 . Fungsi sosial dari suatu adat atau pranata sosial pada tingkat abstraksi ketiga mengenai pengaruh atau efeknya terhadap kebutuhan mutlak untuk berlangsungnya secara terintegrasi dari suatu sistem sosial yang tertentu. Malinowski juga menjelaskan tentang inti teorinya bahwa segala aktivitas kebudayaan itu sebenarnya bermaksud memuaskan suatu rangkaian dari sejumlah kebutuhan naluri makhluk manusia yang berhubungan dengan seluruh kehidupannya. Dengan paham itu, kata Malinowski, seorang peneliti dapat menganalisa dan menerangkan banyak masalah dalam kehidupan masyarakat dan kebudayaan manusia.

Penelitian selanjutnya dilakukan oleh Hasmar Husein Rangkuti mengenai penggunaan Tuor ini dalam perkawinan di Desa Ampung Julu Kecamatan Batang Natal, menurut masyarakat tradisi penggunaan Tuor dapat mempermudah pengantin untuk melaksanakan pesta atau Margondang dan biaya lainnya seperti peralatan rumah tangga (Rangkuti, 2020). Seterusnya penelitian perrnah dilakukan oleh Santi, Salimin A, dan Irawaty inti dari penelitiannya Perkawinan adat etnis Cia Cia menurut praktek hukum adat Wabula yang didasarkan pada stratifikasi sosial masyarakat. Etnis Cia Cia terdiri dari golongan Kaomu, Awalaka, dan Maradika. Adapun jumlah maskawin dalam setiap golongan tersebut sangatlah berbeda-beda (Santi, A, \& Irawaty, 2020). Perbedaan penelitian dengan penelitian yang sudah ada bahwa penelitian ini membahas fungsi Tuor pada masyarakat Mandailing yang menyebabkan adat tersebut tetap dipertahankan hingga kini, hal tersebut yang menyebabkan keterbaruan pada artikel ini.

\section{Metode Penelitian}

Penelitian ini dilakukan di Jorong Ranto Panjang, Nagari Rabi Jonggor, Kecamatan Gunung Tuleh, Kabupaten Pasaman Barat. Dipilihnya masyarakat Mandailing di Ranto Panjang sebagai lokasi penelitian karena pemeberian Tuor masih dipertahankan hingga kini. Pendekan yang dipilih yaitu pendekatan kualitatif dengan tipe etnografi (Bungin, 2005). Pendekatan ini dipilih karena memberi peluang untuk mengenali informasi, guna mendapatkan pemahaman mendalam tentang fokus penelitian. Sementara melalui tipe etnografi, memungkinkan bagi peneliti untuk menggali pengalaman subyek dalam kehidupan sehari-hari dengan mengamati,

Culture \& Society: Journal of Anthropological Research Vol. 3, No. 2, Th. 2021 
mewawancarai mereka dan orang lain yang berhubungan. Informan dalam penelitian dipilih secara purposive sampling. Informan berjumlah 13 orang, terdiri dari: tokoh adat 5 orang, tokoh pemerintahan nagari 1 orang, dan orang yang pernah melaksanakan adat Tuor 7 orang. Data dianalisis dengan mengacu pada teknik analisis etnografi yang dikembangkan Miles dan Huberman (Amalia, 2020), dengan langkah: (1) data reduction (reduksi data); (2) display data (penyajian data); (3) verification analysis (menarik kesimpulan);. Selanjutnya menghasil sebuah karya ilmiah yang bisa dipertanggungjawabkan secara akademik dan metodologis.

\section{Hasil dan Pembahasan}

\section{Orang Mandailing di Nagari Rabi Jonggor}

Nagari Rabi Jonggor terletak di Kecamatan Gunung Tuleh Kabupaten Pasaman Barat Provinsi Sumetera Barat. Dengan luas nagari 289, 89 Kilo Meter persegi. Jarak dari Kabupaten Pasaman Barat ke Kecamatan Gunung Tuleh sekitar $\pm 36 \mathrm{~km}$ dapat ditempuh sekitar satu \pm 1 jam perjalanan, sedangkan jarak dari Kecamatan Gunung Tuleh menujuNagari Rabi Jonggor $\pm 11 \mathrm{~km}$ dengan waktu perjalanan \pm 20 menit, sedangkan jarak dari Nagari Rabi Jonggor menuju Jorong Ranto Panjang sekitar $\pm 3 \mathrm{~km}$ dengan waktu perjalanan \pm 5 menit.

Jumlah penduduk nagari Rabi Jonggor pada tahun 2018 berjumlah 12415 jiwa. terdiri dari 6119 laki-laki dan 6296 perempuan, serta 3566 rumah tangga. Nagari Rabi Jonggor memiliki 16 Nagari (Nel Afrilia, 2019) yaitu: Sitabu, Robi Jonggor, Ampung Basang, Bandar, Paroman, Tanjung Durian, Baruh Gunung, Paroman, Bandar Bulu, Laga Sibatutu, Guo, Siligawan, Ranto Panjang, Air Dingin, Ampung Sorik, Siligawan Menek. Penggunaan lahan di Nagari Rabi Jonggor terdiri dari sawah, karet, kelapa sawit, kelapa, dan lainnya.

Kondisi sosial masyarakat Nagari Rabi Jonggor mempunyai budaya dan adat istiadat yang hampir sama dengan Jorong induknya yaitu Paraman Ampalu. Gabungan masyarakat Nagari Rabi Jonggor terdiri dari masyarakat Mandahiliang, Minang, dan Jawa. Masyarakat di Nagari ini $90 \%$ terdiri dari Mandailiang walaupun masyarakatnya beragam tetap mampu menjaga ketertiban dan hubungan yang akrab antar penduduk serta memiliki nilai gotong royong yang cukup tinggi. Secara tradisonal yang memerintah di Nagari Rabi Jonggor adalah Raja yang bermarga Lubis dan memiliki kekeuasaan di daerah menurut adat istiadat Dalam bidang perekonomian Nagri Rabi Jonggor potensi dalam mengembangkan pendapatan penduduk baik dari pertanian, perkebunan, wisata dan lainnya.

\section{Tuor dalam Budaya Mandailing di Ranto Panjang}

Masyarakat di Jorong Ranto Panjang memiliki kebudayaan dan adat istiadat beragam, baik dalam perkawinan, kematian maupun upacara adat. Hal ini merupakan konsekuensi logis dari keanekaragaman masyarakat, seperti Mandailing, Minang, Melayu, dan Jawa. Oleh karena itu tidak menutup kemungkinan terjadinya tukar menukar budaya antar masyarakat yang berlatar belakang budaya berbeda tersebut. Contoh dalam upacara perkawinan orang Mandailing, pakaian penganten perempuan adalah baju 'Bundo Kanduang' serta Sunting yang menjadi ciri khas budaya Minang.

Seperti yang samapaikan oleh (Erwin, 53 tahun)

"...Sangkak sian minang, unggeh sian Tapanuli na artina wilayah nitaon man minang tai alak dot adat na, man mandailing Tapanuli."

Artinya:

...Sangkar dari minang, burung dari daerah Tapanuli yang artinya wilayah yang ditempati berasal dari daerah minang akan tetapi orang dan adat yang di jalankan berasal dari daerah Tapanuli. 
Meskipun demikian, tatanan masyarakat tetap kuat hal ini dapat dilihat pada acara upacara adat baik upacara perkakawinan maupun upacara syukuran, pada masyarakat Mandailing di dalam acara adat masih menggunakan Markobar atau Marhata-hata (bertanya jawab) dalam bahasa adat dan penjamuan dilaksanakan sesuai adat istiadat yang ada dengan tetap meninggikan seorang Raja yang masih melekat erat.

Masyarakat Jorong Ranto Panjang sebagian besar penduduknya adalah penduduknya asli Mandailing dan sebagian kecil pendatang. Bahasa yang dipakai dalam berinteraksi di daerah ini adalah bahasa Mandailing dan bahasa Indonesia sebagai bahasa minoritas. Sistem kekerabatan orang Mandailing diambil dari garis keturunan ayah atau Patrilineal dengan menggunakan Marga sebagai identitas. Orang Mandailing berkeyakinan bahwa kesejahteraan dan kebahagian akan terwujud apabila ketiga unsur Dalihan Na Tolu fungsional dan bersatu sebagaimana halnya dengan eksistensi manusia yang terdiri dari tiga unsur yaitu Hosa (nafas), Mudar (darah), Juhut (daging) (Bedriati, 2019) Posisi Dalihan natolu akan terlihat pada acara upacara-upacara adat dan merupakan satu kesatuan yang menopang atau sebagai pendukung dalam masyarakat Mandailing. Hak waris pada adat mandailing jatuh pada pihak laki-laki hal tersebutlah yang menjadi salah satu penyebab tuor diserahkan oleh pihak laki-laki dan salah satu adat yang masih dipertahankan hingga kini.

Tuor merupakan salah satu adat sebelum pelaksanaan pesta perkawinan pada masyarakat Mandailing di Pasaman barat. Setiap pasangan yang ingin melaksanakan perkawinan dengan gadis di Jorong Ranto Panjang harus diawali adat Tuor. Penetapan Tuor dilakukan dalam acara Marsapa (meminang). Waktu untuk pelaksanaan adat Tuor atas dasar kesepakatan antara kedua pihak keluarga.

Seperti yang dituturkan oleh (Namlis, 59 tahun)

"...Panontuon waktu ni acara adat Tuor lazimna dilakuon di borgin niari, harana ulang so targanggu kagiatan di siang niari inda targanggu, tai pala adang kendalana dilakuon di borngin niari bisa juo dilaksanaon arian, I sudena atas kesepakatan man dua bolah pihak dohot hatobangan nadi ampungon, inda adaong sanksi namamikat dalom manontuon waktu palaksaannai..."

Artinya:

...Lazimnya adat Tuor dilakukan pada malam hari, agar aktivitas keseharian tidak terganggu, akan tetapi jika ada kendala dilaksanakan pada malam hari bisa dilaksanakan pada siang hari, hal tersebut atas dasar kesepakatan kedua belah pihak beserta Hatobangan dan tidak ada sanksi yang mengikat dalam menentukan waktu pelaksanaannya.

Adat Tuor itu dilaksanakan di rumah orang tua perempuan, Jumlah kerabat yang menghadiri dilihat dari kondisi rumah si perempuan berapa orang yang bisa ditampung. Lazimnya yang dihadiri oleh keluarga perempuan sebagai penerima tamu yaitu: ayah, Umak (ibu), Uen (kakek), nenek, Bapak (saudara laki-laki ayah); Etek (saudara perempuan ibu); Mamak (saudara lakilaki ibu); Uci (saudara perempuan ayah) adik, kakak, abang serta kerabat dekat lainnya atau yang mewakili. Pihak yang datang dari keluarga laki laki yaitu: ayah, ibu, kakek, nenek, Bapak, Etek, Uci, Mamak, adik, kakak, abang serta kerabat lainnya atau yang mewakili. pihak Hatobangan kampung (Raja, Ripe, Khatif, Imam, Tokoh Agama) atau yang mewakili". Jika calon istri tidak memiliki orang tua atau kedua orang tuanya sudah meninggal maka tempat pelaksaan adat Tuor dilaksanakan di rumah saudara ayahnya. Apabila calon isteri diasuh oleh orang lain, maka tempat pelaksanaan adat Tuor sesuai dengan kesepakatan pihak keluarga perempuan. Adat pemberian Tuor masih dipertahankan masyarakat hingga saat ini karena masih dianggap penting. Berikut halhal yang menyebabkan pentingya adat Tuor dalam masyarakat Mandailing di Ranto Panjang. 


\section{Fungsi Tuor}

Pertama, penguatan ikatan dua keluarga. Perkawinan adalah suatu peralihan dalam jenjang kehidupan seseorang sehingga mampu menciptakan suatu ikatan khusus yang membentuk tatanan masyarakat. Secara sosiologis, perkawinan adalah penerimaan status baru untuk siap menerima hak dan kewajiban sebagai pasangan suami isteri yang sah diakui masyarakatnya dan hukum (Wulya, 2007). Menurut (Narwoko \& Suyanto, 2006) dalam jurnal (Hidayat, 2015) merupakan suatu sistem norma dan tata cara yang diterima untuk menyelesaikan sejumlah tugas penting. Secara umum, ada beberapa pranata sosial sebagi untuk berhubungan dengan keluarga inti (nuclear family) dan hal ini juga merupakan sebuah upaya atau langkah-langkah untuk saling menyesuaikan diri diantara kedua belah pihak pasangan pria dan wanita sebelum mengikatkan diri pada jenjang pernikahan, yaitu: pertama, pranata kencan (dating); kedua, pranata peminangan (courtship); ketiga, pranata pertunangan (mate selection); keempat, pranata pernikahan (marriage)

Empat tahapan tersebut di atas merupakan serangkaian tahapan yang saling berkaitan dan berhubungan untuk menuju terbentuknya suatu keluarga. Jadi idealnya, jika empat tahapan tersebut dilalui, maka akan terbentuk dan tercipta sebuah keluarga yang bahagia, karena kedua belah pihak tersebut sudah mengadakan interaksi sosial yang intens untuk saling mengenal dan menyelidiki kepribadian dari mereka masing-masing serta membandingkan dengan teliti mengenai perangainya, kepentingannya, dan cita-citanya demi menguji kesejajaran pasangan dalam segala hal sehingga tidak sulit untuk mengadakan penyesuaian. Sebaliknya, akan terkesan aneh dan tentunya penuh risiko apabila dalam terbentuknya sebuah keluarga tidak melalui tahapan-tahapan penjajakan se-intens dan selama sebagaimana tersebut di tas, apalagi diberi batasan-batasan dalam proses penjajakannya. Secara kasatmata, proses penjajakan dengan waktu yang singkat baik dari interaksi sosial dan dalam pengambilan keputusan untuk menikah, kemungkinan besar akan memunculkan potensi konflik dan akan berujung pada perceraian dalam rumah tangganya, dikarenakan kurangnya saling mengenal dan menyelidiki kepribadian dari mereka masing-masing serta kurangnya membandingkan dengan teliti mengenai, kepentingannya, dan cita-citanya demi menguji kesejajaran dengan pasangan.

Oleh karena itu, perkawinan tidak hanya menyangkut hubungan kedua mempelai atau calon pengantin saja, namun melibatkan keluarga besar kedua belah pihak. Agar hubungan perkawinan kedua mempelai dapat berjalan lancar dan selaras, mereka terlebih dahulu melakukan penyesuaian diri terhadap pasangannya satu sama lain. Karena pasangan tersebut berasal dari latar belakang keluarga ataupun adat yang berbeda.

Seperti yang disampaikan oleh (Makhruf, 51 tahun)

"Adat Tuor dinilai amat penting karena dengan adanya Tuor pasangan tersebut mendapat legitimasi (pengakuan) dari keluarga laki-laki dan perempuanbeseta masyarakat".

Legitimasi dari keluarga menyebabkan hubungan keluarga pihak laki-laki dan perempuan semakin erat dan membuat ikatan keluarga menjadi luas, karena sebelum diadakan adat penentuan Tuor ada penjajakan dari pasangan tersebut bersama ayah dan ibunya beserta keluarga luas untuk menetapkan hari dan waktu pelaksanaan adat Tuor, dari proses tersebut dapat meningkatkan solidaritas kelompok atau hubungan kedua keluarga calon mempelai semakin erat. Adat penetapan Tuor bisa menjadi bahan omongan di masyarakat jika besarnya Tuor yang disepakati tidak sebanding dengan status pendidikan si calon isteri.

Seperti yang diungkapkan oleh (Eva Gusti,51 tahun)

"...Panontuon acara masrsapaon hubungan keluarga bisa madonok, harana di acara marsapon kinnai pasti dikumpulkan keluarga ni alak mambaen acara nai, harus ken adong do kesepakatan dot keluarga godang nalai so bisa dilaksanon acara naonan...". 


\begin{abstract}
Artinya:
...acara penentuan Tuor ini menyebabkan hubungan keluarga bisa menjadi lebih erat, karena saat acara dibuat keluarga besar akan dikumpulkanan acara ini bisa terlaksana atas kesepakatan keluarga besar.

Hal yang sama juga disampaikan oleh (Tarmizi, 61 tahun).

"Ompak acara marsapa anak ni angikku hubungan keluargaku dot keluarga nalai membaik, hampir 5 tahun keluarga nami inda marsipangecek an harana adong masalah lahan sakaliani, tai baen git mangadaon acara adat Tuor anak nyiai disi keluarga nami mardengganna".

Artinya:

...waktu acara Marsapa anak dari adik aku menyebabkan hubungan keluarga kami menjadi baik se telah hampir 5 tahun kami tidak saling bicara karena kami waktu itu ada permasalahan mengenai tanah.
\end{abstract}

Disisi lain dengan melaksanakan adat Tuor membuktikan keseriusan laki-laki untuk menikahi gadis pilihannya yang secara tidak langsung menimbulkan rasa percaya dari orang tua si gadis dan menyebabkan calon mempelai mendapat izin pergi berdua dalam rangka mengurus segala proses pernikahan tanpa menimbulkan rasa curiga masyarakat. Selanjutnya penetapan Tuor bisa sebagai penguatan ikatan antar insan yang saling menyayangi sehingga dianggap fungsional dalam masyarakat.

Malinowski juga beranggapan bahwa teori tentang unsur-unsur kebudayaan itu sangat kompleks, bahwa segala aktifitas kebudayaan sebenarnya bermaksud memuaskan suatu rangkaian dari sejumlah kebutuhan naluri makhluk manusia yang berhubungan dengan seluruh kehidupannya (human need) (Nurhasanah, 2019). Sama halnya dengan adat Tuor yang merupakan kebutuhan manusia yaitu kebutuhan sosialnya untuk diakui di kedua pihak perempuan dan pihak laki-laki serta masyarakat.

Kedua, Menjunjung Tinggi Tradisi yang Diwarisi dari Generasi Terdahulu, hingga kini adat Tuor tetap dipertahankan karena masyarakat Ranto Panjang menjunjung tinggi adat tersebut. Tuor yang ditetapkan atas dasar kesepakatan yang konsrukif. Penetapan besarnya Tuor pada acara Marsapa mengandung kehormatan kedua belah pihak yaitu keluarga laki-laki dan keluarga perempuan, sehingga pada saat acara ini bisa saja menimbulkan polemik diantara kedua keluarga pasangan dalam menentukan besarnya Tuor yang diminta.

Seperi yang disampaikan oleh (Eva Gusti):

Ompak acara penentuan Tuor anak ku sakliani terjadi perdebatan keluarga nami dot keluarga man alak lai, anakku kan lulusan S1 jadi ami paido Tuor nia 15.000.000 magodang tu lala keluarga bayoi jadi tarjadima tawar manawar diantara ami kesepakatan akhirna 13.000.000 domana.

Artinya:

.. waktu acara penentuan Tuor anak saya waktu itu terjadi perdebatan antara keluarga laki-laki dan keluarga perempuan, anak saya lulusan S1 jadi kami meminta Tuor sebanyak 15.000.000 akan tetapi dari pihak laki-laki membantah karena merasa terlalu besar atau mahal maka terjadilah tawar m enawar kedua belah pihak dan keputusan akhirnya 13.000.000).

Jika pasangan yang ingin melaksanakan perkawinan, tetapi tidak melaksanakan adat Tuor maka masyarakat akan menganggap mereka sebagai pasangan yang rendah stratifikasi mereka tersebut. Sehingga akan mendapat sanksi yang ditetapkan secara adat. 
Seperti yang disampaikan oleh Namlis dan Erwin.

"...Pala adong pasangan inda malaksanon ada Tuor ken adong sanksi na ditarimo nalai ima inda ken dilaksanon dialai golarna Obar Adat".

Artinya:

Bahwa pasangan yang tidak melaksanakan adat Tuor maka ada sanksi yang diterima yaitu tidak dilaksanakan Obar Adat.

Obar Adat adalah pengumuman oleh elit tradisional (Hatobangan Kampung) kepada masyarakat, bahwa pasangan tersebut telah malakukan adat yang berlaku pada masyarakat Jorong Ranto Panjang. Obart Adat ini dilaksanakan pada malam hari setelah acara pesta perkawinan, jika ada pasangan yang tidak melaksanakannya, maka tidak akan dilindungi secara adat oleh Hatobangan kampung setempat. Oleh sebab itu masyarakat menganggap adat Tuor sebagai tradisi lama serta kebiasaan yang masih dilestarikan karena sangat bernilai sampai saat sekarang ini.

Bronislaw Malinowski mengajukan sebuah orientasi teori yang dinamakan fungsionalisme, yang beranggapan atau berasumsi bahwa semua unsur kebudayaan bermanfaat bagi masyarakat dimana unsur itu terdapat. Dengan kata lain pandangan fungsionalisme terhadap kebudayaan mempertahankan bahwa setiap pola kelakuan yang sudah menjadi kebiasaan, setiap kepercayaan dan sikap yang merupakan bagian dari kebudayaan dalam suatu masyarakat, memenuhi beberapa fungsi mendasar dalam kebudayaan bersangkutan (Kristianto, 2019). Sama halnya dengan adat Tuor yang merupakan kebudayaan yang tetap dipertahankan dan menjadi kebiasaan karena dianggap penting oleh masyarakat Jorong Ranto Panjang di Kabupaten Pasaman Barat.

Ketiga, Penghormatan Terhadap Orang Tua Si Gadis. Pemberian Tuor Pada masyarakat Mandailing di Jorong Ranto Panjang diaganggap sebagai penghormatan bagi orang tua si gadis, yang telah membesarkan dan menyekolahkan anak perempuan yang ia cintai, apalagi setelah pesta perkawinan suami memboyong isteri kekediamannya dan bergabung kekerabat orang tua pihak keluarga laki-laki. Berangkatnya isteri dari kediamannya membuat rasa kehilangan yang mendalam bagi keluarga, terutama bagi orang tua sigadis, meskipun hubungan dengan keluarga ayah dan ibunya tidak berubah. Akan tetapi tetapi dengan diadakannya adat Tuoryang merupakan tanda terimakasih dari pihak laki-laki. Setiap orang pasti bangga jika semua persyaratan dalam perkawinan terlaksana dengan baik, baik secara adat maupun hukum, serta orang tua pihak perempuan merasa bangga jika anak perempuannya telah menemukan laki-laki yang meminangnya yang mampu memberikan Tuor yang diminta oleh keluarganya.

Seperti yang disampaikan oleh (Emmi, 48 tahun):

"Tinggi atau rendahnya uang Tuor yang diberikan mempunyai makna tersendiri".

Juga disampaikan oleh ani Junita, 25 tahun

"Au sakaliani inda direstui orang tuaku gitmarbagas au dohot gandakku sebelum nai harana inda disanggupi ia tuor nadipangido nalai. Tuor nadipangido alak umak Rp.15. 000.000 ia nasanggup pia ditoru Rp.10.000.000, ndara alak umak harana baen baen tamat kuliah S1 au".

Artinya:

...waktu itu saya tidak dikasih restu oleh orang tuaku untuk menikah dengan pacar aku, karena dia tidak menyanggupi besarnya Tuor yang dimita. Jumlah Tuor yang diminta Orang tuaku sebesar Rp.15.000.000 akan tetapi dia hanya menyanggupi dibawah Rp.10.000.000 tetapi tidak diberi izin karena saya tamatan S1.

Kesanggupan laki-laki memberikan Tuor yang diminta oleh keluarga pihak perempuan, mengandung makna bahwa si laki-laki bukan sembarang menikahi si gadis melainkan tanggung jawab penuh. dengan bukti diberikan Tuor sesuai dengan permintaan keluarga pihak perempuan. Bagi keluarga pihak laki-ki dengan menyanggupi Tuor yang diminta pihak keluarga perempuan merupakan suatu kehormatan. Sebaliknya bagi keluarga perempuan bahwa anaknya telah 
mendapat calon suami pilihannya yang sanggup memberikan Tuor sesuai dengan permintaan orang tuanya. Hal tersebut membuktikan bahwa keluarga pihak perempuan tidak termarjinalkan dari masyarakat jika mereka orang yang dimarjinalkan maka pihak laki-laki tidak akan menyetujui besarnya Tuor yang diminta.

Menurut Malinowski konsep mengenai fungsi sosial dari adat, tingkah laku manusia, dan psranata-pranata sosial menjadi mantap yang kemudian ia membedakan fungsi sosial dalam tiga tingkat abstraksi dalam buku (Koentjaraningrat, 1982) yaitu: (1) Fungsi sosial dari suatu adat, pranata sosial pada tingkat abstraksi pertama mengenai pengaruh tingkah laku manusia dan pranata sosial dalam masyarakat; (2) Fungsi sosial dari suatu adat, pranata sosial pada tingkat abstraksi kedua mengenai pengaruh suatu kebutuhan suatu adat yang sesuai dengan konsep masyarakat yang bersangkutan; (3)Fungsi sosial dari suatu adat, pranata sosila pada tingkat abstraksi ketiga mengenai pengaruh terhadap kebutuhan mutlak untuk berlangsungnya secara terintegrasi dari suatu sistem sosial tertentu (Nurhasanah, 2019). Berdasarkan tingkat abstraksi pertama bahwa pasangan yang melaksanakan adat Tuor mendapat perlakuan baik dari masyarakat karena telah melaksanakan adat yang berlaku dalam masyarakat setempat.

Keempat, Penghargaan terhadap status pendidikan perempuan. Dahulu pemberian Tuor pada masyarakat Mandailing di Jorong Ranto Panjang tidak berdasarkan status pendidikan seorang perempuan melainkan dilihat dari keturunan orang tuanya (Namlis, 59 tahun). Misalnya jika orang tua dari calon istri merupakan bagian dari elit tradisional, maka Tuor yang diberikan akan lebih tinggi dibandingkan dengan gadis yang orang tuanya dari kalangan biasa. Kemudian, di era modren ini pembarian Tuor berubah, seiring perkembangan zaman yang semakin maju masyarakat khususnya di Ranto Panjang menilai tinggi pendidikan perempuan. Sehingga berdampak pada Tuor yang harus diberikan pihak laki-laki. Semakin tinggi tingkat pendidikan seorang perempuan maka semakin tinggi pula Tuor yang diminta oleh orang tuanya. Hal tersebut karena mereka menganggap perempuan yang dinikahinya tersebut tidaklah perempuan yang termarjinalkan dari masyarakat.

Dewasa ini jumlah Tuor yang harus diserahkan bagi laki-laki kepada calon istri dengan status pendidikannya di bawah lulusan sekolah SMA Rp. 5.000.000,- (lima juta rupiah); lulusan SMA antara Rp.5000.000,- (lima juta rupiah) sampai dengan Rp. 10.000.000,- (sepuluh juta rupiah); lulusan Strata Satu (S-I) antara Rp. 10.000.000,- (sepuluh juta rupiah) sampai dengan Rp. 15.000.000,- (lima belas juta rupiah); jika lulusan di bidang kesehatan antara Rp. 15.000.000,(lima belas juta rupiah) sampai dengan Rp. 20.000.000,- (dua puluh juta rupiah). Selain itu, nilai Tuor bisa bertambah berdasarkan performa si calon isteri yang dilihat dari kealiman, kecantikan, dan status ekonomi, akan tetapi hal tersebut hanya penambah nilai Tuor dari rata-rata yang telah ditetapkan sesuai dengan status pendidikan perempuan.

Besarnya Tuor yang akan diberikan tidak tertulis secara hukum akan tetapi jika calon suami si perempuan tidak memberikan Tuor sesuai dengan pendidikan calon isterinya maka pasangan tersebut menjadi bahan pembicaraan oleh masyarakat setempat.

Seperti yang disampaikan oleh Rahmah, 52 tahun

"Tuor i memang inda adong hukumna natartulis tai pala inda sesui godangna tuor nadilehen dohot sikola ala borui bisa jadi bahan olok-olokan di masyarakaton, harana masyarkat memang waktu panontuan godangna tuor i hum keluarga dua belah pihak mia nadohot, tai pasti de bonggal di masyarakaton sajia tuor nadisapakati di acarai mungkin man kelauarga naroi bisa jadi didokon ia di alakna lain sehingga tarsebar luas".

Artinya:

Jika Tuor yang diberikan tidak sesuai dengan pendidikan perempuan bisa jadi bahan olok-olokan bagi masyarakat, walaupun masyarakat tidak mengikuti acara penentuan Tuor, dari keluarga yang menghadiri bisa jadi menyampaikan kepada orang lain besarnya Tuor yang ditetapkan sehingga tersebar luas di masyarakat.

Culture \& Society: Journal of Anthropological Research Vol. 3, No. 2, Th. 2021 


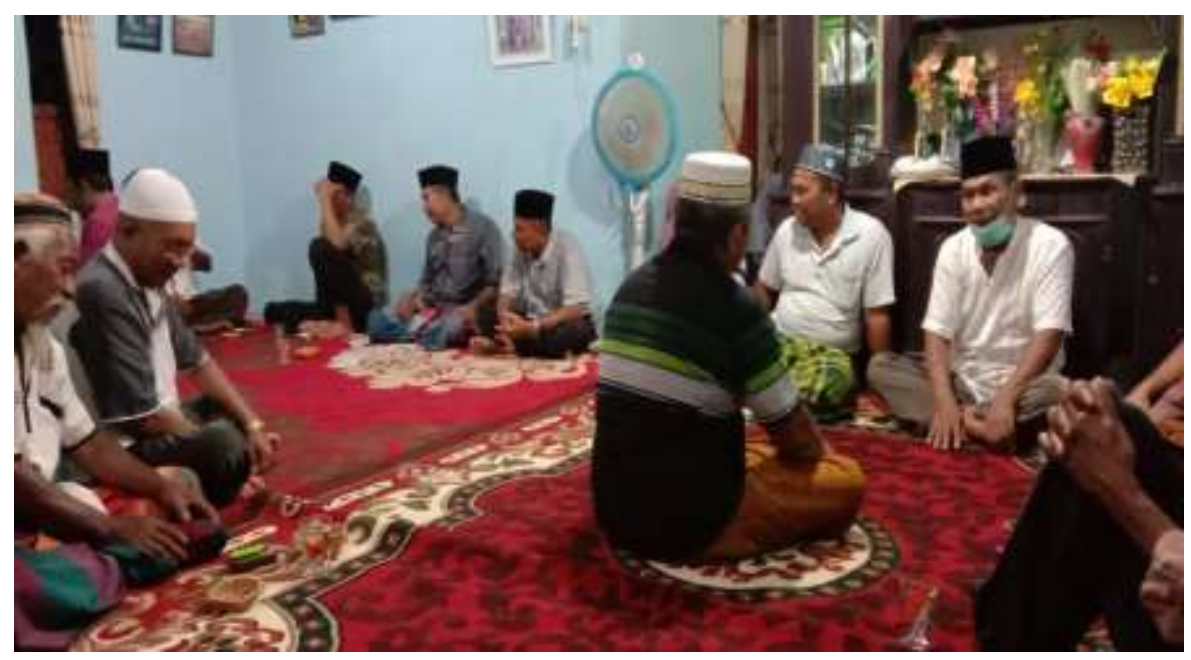

Gambar 1. Acara penentuan Tuor diruma fika

Begitu juga yang dikatakan oleh Malinowki fungsi sosial dari suatu adat, pranata sosial pada tingkat abstraksi kedua mengenai pengaruh suatu kebutuhan suatu adat yang sesuai dengan konsep masyarakat yang bersangkutan.

Kelima, Mendapatkan pengakuan Perkawinan Secara Adat. Pasangan yang melaksanakan adat Tuor maka akan mendapat legalitas atau pengakuan dari adat. Tanpa pemberian Tuor legalitas perkawinan seseorang secara adat akan lemah, buktinya jika pasangan yang tidak membayar Tuor maka mereka tidak diakui secara adat oleh Hatobangan Kampung dan masyarakat setempat. karena telah melanggar adat yang telah menjadi kebiasaan masyarakat sejak dahulu.

Seperti yang di ungkapkan oleh (Mirdan, 50 tahun).

"Hilang minta dicari,

Mati minta ditanam

Kurangnya minta diajari

Maksudnya segala kemaslahatan di tengah masyarakat telah setara dengan masyarakat lain atau segala urusan diurus oleh masyarakat lain. Artinya kita sebagai makhluk sosial tidak bisa hidup tanpa orang lain. Masyarakat Mandailing di Ranto Panjang menganggap perkawinan yang baik adalah perkawinan yang sesuai dengan adat yang berlaku di masyarakat, sehingga pasangan yang melanggar adat tersebut bisa mendapat sanksi adat. seperti surat keterangan tanah yang membutuhkan bantuan dari elit masyarakat tertentu maka mereka tidak mau memberikannya dan masyarakat setempat tetap menganggap rendah meskipun pasangan tersebut telah mandapatkan legalitas dari KUA (Kantor Urusan Agama). Oleh karena ketakutan pasangan mengenai klaim masyarakat setempat membuat pasangan yang ingin melaksanakan perkawinan harus malaksankan adat Tuor terlebih dahulu. Dengan demikian adat Tour mempengaruhi pranata agama dan pranata adat masyarakat dimana; segala aktivitas kebudayaan itu sebenarnya memberikan kepuasan terhadap kebutuhan naluri manusia yang berhubungan dengan kehidupannya. Kebutuhan yang meliputi kebutuhan biologis (primer) maupun Psikologis (sekunder) yang menjadi kebutuhan dasar yang muncul dari kebudayaan itu sendiri (Peter Connolly (ed.). 2011).

Menurut Malinowski konsep yang menyatakan fungsi sosial dari suatu adat dapat mempengaruh tingkah laku manusia, terhadap pranata serta kebutuhan adat dan kebutuhan mutlak demi keberlangsungan sistem sosial tertentu (Nurhasanah, 2019). Adat Tuor merupakan serangkaian kegiatan tingkah laku yang memiliki pranata sosial dan pranata adat dengan sistem sosialnya yang terdiri dari sejumlah fungsi ditengah-tengah masyarakat sehingga dipertahankan hingga saat ini. Adat Tuor inilah yang dianggap dapat memenuhi dan memuaskan suatu rangkaian dari sejumlah kebutuhan naluri makhluk manusia yang berhubungan dengan seluruh 
kehidupannya. Selain itu adat Tuor dianggap dapat menyelesaikan masalah dalam proses perkawinan masyarakat adat orang Mandailing di Ranto Panjang. Tidak hanya itu adat Tuor juga mempengaruhi tingkah laku masyarakat dimana warga yang mengikuti adat Tuor harus mematuhi aturan yang telah dibuat dan bagi yang melanggar akan mendapatkan sanksi yang disepakati oleh masyarakat, sehingga pasangan yang ingin melaksanakan perkawinan terikat terhadap aturan yang telah dibuat dan disepakati bersama tersebut.

\section{Kesimpulan}

Setiap pasangan yang ingin melaksanakan perkawinan dengan gadis di Jorong Ranto Panjang harus diawali adat Tuor. Penetapan Tuor dilakukan dalam acara Marsapa (meminang). Besarnya Tuor yang harus diserahkan si laki-laki ditentukan oleh pihak keluarga perempuan dengan mempertimbangkan status pendidikan calon isterinya. Berdasarkan temuan penelitian, dapat disimpulkan bahwa fungsipemberian Tuor bagi masyarakat yaitu: (1) penguatan ikatan dua keluarga; (2) Menjunjung Tinggi Tradisi yang Diwarisi dari Generasi Terdahulu; (3) Penghormatan Terhadap Orang Tua Si Gadis; (4) Penghargaan terhadap status pendidikan perempuan; (5) Mendapatkan pengakuan Perkawinan Secara Adat.

\section{Daftar Pustaka}

Amalia, I. (2020). Penerapan Permainan Tradisional Anjang-Anjangan Dalam Penguata Nilai Karakter Sopan Santun Anak Berbasis Perilaku Sosial Kewarganegaraan Universitas Pendidikan Indonesia. Universitas Pendidikan Indonesia.

Bedriati, T. (2019). Sistem Kekerabatan Suku Mandailing Di Kecamatan Rumbali Pesisir Kota Pekan baru. JOM FKIP, 6(1), 1-8.

Bungin, B. (2005). Analisis Data Penelittian Kualitatif. Jakarta: Prenadamedia.

Ferdian, E. (2021). Batasan Jumlah Mahar (Maskawin) Dalam Pandangan Islam Dan Hukum Positif. Jurnal Ilmiah Ahwal Syakhshiyyah, 3(1).

Hidayat, A. F. (2015). Penyesuaian Pasanagan Pernikahan Hasil Ta'aruf. E-Sospol, 2(1), 59-67.

Koentjaraningrat, K. (2005). Pengantar Antropologi Jilid II. Jakarta: Rineka Cipta.

Kristianto, I. (2019). Kesenian Reyog Ponorogo dalam Teori Fungsionalisme. Tamumatra: Jurnal Seni Pertunjukan, 2(1), 6-18. https://doi.org/10.29408/tmmt.v1i2.xxxx

Lanna, K. (2019). Mangalehen Tuor: Fenomena Living Hadis dalam Adat Mandailing. Mashdar: Jurnal Studi Al-Qur'an Dan Hadis, 1(1).

Nel Afrilia, D. (2019). 2006-2001-2006, Analisis Perubahan Penggunaan Lahan Di Daerah (DAS) Babatang Kenaikan Bagian Hilir Kabupaten Pasaman Barat. Jurnal Buana, 3, 1129-1142.

Nurhasanah, M. (2019). Persepsi Dosen Prodi PGMI dan PGRA terhadap Remunerasi di UIN Raden Intan Lampung. Al-Idarah: Jurnal Kependidikan Islam, 9(1).

Rangkuti, H. H. (2020). Tradisi Tuor Dalam Perkawinan Studi Di Desa Ampung Julu Kecamatan Batang Natal Kabupaten Mandailing Natal. Disertasi. IAIN Padangsidempuan

Reski, K. (2016). Persepsi Masyarakat Terhadap Uang Panai' Di Kelurahan Pattalassang Kecamatan Pattalassang Kabupaten Takalar. Alauddin Makasar. Disertasi. UIN Alauddin Makassar

Roni, Z.P. (2016). Tradisi Uang Japuik dan Status Sosial Laki-Laki. Universitas Islam Negeri Syarif Hidayatullah.

Siregar, S. (2019). Hubungan Penentuan Tuhor dengan Terlaksananya pernikahan di Desa Sosopan Kecamatan Sosopan Kabupaten Padang Lawas. Disertasi. IAIN Padangsidempuan 
Santi, S., A, S., \& Irawaty, I. (2020). Penyebab Perbedaan Jumlah Mahar Dalam Kawin Pinang (Pika Bheka-Bheka) Pada Masyarakat Etnis Cia Cia (Studi di Desa Wabula Kecamatan Wabula Kabupaten Buton Provinsi Sulawesi Tenggara). Selami IPS, 12(2), 141. https://doi.org/10.36709/selami.v12i2.10846

Thimoty, E. (2019). Tradisi Sinamot Sebagai Bentuk Penghargaan Terhadap Pihak Perempuan di Dalam Hukum Perkawinan Adat Batak Toba Antara Masyarakat Modren dengan Masyarakat Tradisional. Universitas Lampung.

Wulya, B. (2007). Sosiologi Menyelami Fenomena Sosial di Masyarakat. Bandung: PT Setia Puma Inves.

Yunita, S. (2013). Uang Japuik dalam Adat Perkawinan Padang Pariaman di Bandar Lampung. Jurnal Pendidikan Dan Penelitian Sejarah (Pesagi), 1(1).

Zike, M. (2020). Persepsi dan Makna Tradisi Perkawinan Bajapuik pada Masyarakat Sungai Garingging Kabupaten Padang Pariaman. Biokultur, 9(1), 20. https://doi.org/10.20473/bk.v9i1.21725 